University of Nebraska - Lincoln

DigitalCommons@University of Nebraska - Lincoln

Faculty Publications: Department of Entomology

2021

\title{
Landscape characterization of floral resources for pollinators in the Prairie Pothole Region of the United States
}

\author{
Autumn H. Smart \\ University of Nebraska-Lincoln, asmart8@unl.edu \\ Clint R.V. Otto \\ USGS, Northern Prairie Wildlife Research Center, cotto@usgs.gov \\ Alisa L. Gallant \\ U.S. Geological Survey (USGS) Earth Resources Observation and Science (EROS) Center, \\ gallant@usgs.gov \\ Michael P. Simanonok \\ USGS, Northern Prairie Wildlife Research Center, msimanonok@usgs.gov
}

Follow this and additional works at: https://digitalcommons.unl.edu/entomologyfacpub

Part of the Entomology Commons

Smart, Autumn H.; Otto, Clint R.V.; Gallant, Alisa L.; and Simanonok, Michael P., "Landscape characterization of floral resources for pollinators in the Prairie Pothole Region of the United States" (2021). Faculty Publications: Department of Entomology. 949.

https://digitalcommons.unl.edu/entomologyfacpub/949

This Article is brought to you for free and open access by the Entomology, Department of at DigitalCommons@University of Nebraska - Lincoln. It has been accepted for inclusion in Faculty Publications: Department of Entomology by an authorized administrator of DigitalCommons@University of Nebraska - Lincoln. 


\title{
Landscape characterization of floral resources for pollinators in the Prairie Pothole Region of the United States
}

\author{
Autumn H. Smart ${ }^{1,2} \mathbb{D}$. Clint R. V. Otto ${ }^{2}$ - Alisa L. Gallant ${ }^{3}$. \\ Michael P. Simanonok ${ }^{2}$ (D)
}

Received: 1 October 2020 / Revised: 12 March 2021 / Accepted: 2 April 2021 / Published online: 17 April 2021 (c) This is a U.S. government work and not under copyright protection in the U.S.; foreign copyright protection may apply 2021

\begin{abstract}
Across agricultural areas of the Prairie Pothole Region (PPR), floral resources are primarily found on public grasslands, roadsides, and private grasslands used as pasture or enrolled in federal conservation programs. Little research has characterized the availability of flowers across the region or identified the primary stakeholders managing lands supporting pollinators. We explored spatial and temporal variability in flower abundance and richness across multiple grassland categories (i.e. general grassland, conservation grassland, and engineered pollinator habitat) in the PPR from 2015 to 2018 and used these data to estimate the number of flowering stems present across the region on private and public land holdings. Both flowering plant abundance and richness were greatest on engineered pollinator habitat, but this land category encompassed $<0.01 \%$ of the total grassland area in the PPR. There was a steady decrease in flower abundance over the growing season across all land categories. We detected considerable variation in flower abundance and richness across grassland categories, indicating that not all natural or semi-natural covers provide similar value to pollinators. At a landscape scale, large land holdings such as privatelyowned grasslands and Conservation Reserve Program lands contributed the greatest number of flowers by an order of magnitude, though these lands collectively did not support the greatest abundance of flowers per unit area. Our research depicts spatial and temporal variation in pollinator resources across the region. Further, our research will assist managers and policy makers in understanding the role of public and private lands and conservation programs in supporting pollinators.
\end{abstract}

Keywords Wildlife habitat · Great Plains · Land use · Conservation grassland · Engineered pollinator habitat

Communicated by Daniel Sanchez Mata.

Alisa L. Gallant-Retired.

Autumn H. Smart

asmart8@unl.edu

Extended author information available on the last page of the article 


\section{Introduction}

Plant-pollinator mutualistic networks serve as the foundation of many terrestrial food webs (Fontaine et al. 2005; Burkle and Alarcon 2011; Burkle et al. 2013). Managed and wild pollinators rely on the presence of floral resources within their foraging ranges to provide nectar and pollen as nutritional resources. In turn, pollinating insects and other animals facilitate sexual reproduction of $85 \%$ of flowering plants globally (Ollerton et al. 2011). Habitat loss through agricultural expansion and intensification can fragment pollinator networks and reduce ecosystem function (Winfree et al. 2009, 2011; Potts et al. 2010).

The Prairie Pothole Region (PPR) of the United States has been identified as a particularly important part of the country for supporting healthy honey bee colonies and a robust pollination industry nationally (Pollinator Health Task Force 2015; Smart et al. 2018). In this region, the states of North Dakota, South Dakota, Minnesota, and Montana host around $30-40 \%$ of the national pool of honey bee colonies throughout the growing season (U.S. Department of Agriculture 2018). This area also supports diverse native pollinator communities and is included in the core migratory range of the iconic monarch butterfly (Danaus plexippus), several bumble bee species (e.g., Bombus pensylvanicus, B. affinis, B. terricola) that are of conservation concern (Cameron et al. 2011; Oberhauser et al. 2017; Evans et al. 2018; Darby et al. 2020), and other native bee communities (Bendel et al. 2019; Lane et al. 2020). Additionally, native grasslands in the PPR harbor numerous species of upland birds and waterfowl (Best et al. 1995; Naugle et al. 2001; Niemuth et al. 2005), and play a critical role in carbon sequestration, nutrient cycling, and soil and water quality for the larger region (Whigham and Jordan 2003; Gleason et al. 2005; Seelig and DeKeyser 2006). Approximately $80-90 \%$ of the landmass in the PPR is privately owned, thereby highlighting the importance of private lands in supporting pollinator health and ecosystem service delivery in the region (Samson and Knopf 1994).

Despite its importance as habitat for diverse wildlife and benefits for ecosystem services and processes, the PPR has experienced rapid changes in land use over the past few decades (e.g., Wright and Wimberly 2013; Lark et al. 2015). Such changes, and the resulting landscapes, negatively impact plant-pollinator networks and communities (Kremen et al. 2007; Kwaiser and Hendrix 2008; Evans et al. 2018). Historical prairie, grasslands, wetlands, and rangelands have given way to row crops such as corn and soybeans, partly as a result of policies calling for increased biofuel crop production, rising commodity crop prices and changes in U.S. Farm Bill conservation programs (Claassen et al. 2011; Rashford et al. 2011; Wright and Wimberly 2013). The move to biofuels to supplement fossil fuel consumption entails numerous unintended environmental consequences (e.g., Pimentel 2003; Searchinger et al. 2008; Tillman et al. 2009), one of which is a decrease in potential suitable forage for both wild and managed pollinators (Koh et al. 2016; Otto et al. 2016, 2018).

Land use change and the importance of the PPR for pollinators has generated considerable interest among government and private entities in preserving remaining grasslands and restoring marginal cropland to pollinator forage lands. For example, federal funding was appropriated through U.S. Farm Bills for the U.S. Department of Agriculture (USDA) to develop multiple pollinator practices and initiatives via the Conservation Reserve Program (CRP) and Environmental Quality Incentives Program (EQIP). These practices and initiatives were designed to enhance the value of private farmland to pollinators. As part of the 2008 Farm Bill, the USDA launched a new pollinator conservation practice within the CRP (Conservation Practice-42, Pollinator Habitat). In 2014, the USDA developed two initiatives within existing conservation programs to further enhance pollinator forage on 
private lands in the Northern Great Plains as well as in the Upper Midwest part of the United States. In addition, private business and non-government organizations concerned with global food production have contributed funds to provide forage for bees. For example, the Bee and Butterfly Habitat Fund (BBHF) was established in 2014 through private partnerships to restore pollinator habitat on private lands in agricultural areas of the midwestern United States. Although the overarching goal of these multiple programs and practices is to promote forage for pollinators, the programs/practices are highly varied with respect to seed mix specifications and financial incentives given to landowners. In addition, many conservation grasslands throughout the PPR were not developed with the objective of providing pollinator habitat, but still have potential to contribute to pollinator conservation. For example, the U.S. Fish and Wildlife Service manages the National Wildlife Refuge system that serves as wildlife habitat. Although some areas within the Refuge system may be managed specifically for pollinators, conservation of migratory birds is usually the primary goal. Many USDA conservation programs were not developed with pollinators as a primary goal, but nonetheless may provide pollinator habitat. Roadside ditches used for drainage control and remnant grasslands used as pasture also have the potential to provide habitat for bees (Hopwood et al. 2015), but these lands are not often managed for this objective.

Although the PPR is a priority area for pollinator conservation and forage enhancement, relatively little work has been done to describe the abundance and richness of floral resources across the multiple land categories present on the landscape. Understanding the spatial and temporal variation in the availability of floral resources across the PPR can inform researchers who are modeling how land use change affects pollinators (Gallant et al. 2014; Koh et al. 2016; Thogmartin et al. 2017; Otto et al. 2018). Researchers investigating the effects of land use change often make assumptions about the ecological value of land categories without understanding how the variation in resources within categories may change across space and time. For example, in our previous assessment of how alteration to the CRP national acreage cap would affect landscape suitability for honey bees, we assumed the quality of CRP grassland was constant across the multiple CRP conservation practices (Otto et al. 2018). Having information on the variability of floral resources among CRP practices would have improved the realism of our landscape model projections. Thogmartin et al. (2017) used expert opinion and state-specific data of milkweed abundance on CRP, roadsides, and other land categories to develop monarch population models for the Eastern United States. Although this work has been instrumental in developing a national target for monarch conservation, the authors acknowledged considerable uncertainty in vegetation estimates across much of their study region. The seminal work on wild bees by Koh et al. (2016) applied indices of land cover quality to infer changes in bee abundance across the United States, but those indices did not consider variation in resource quality within natural and semi-natural land covers. In addition to being important for research, understanding the resource value of different land categories can provide policy makers with the information needed to evaluate the costs and benefits of specific conservation programs and tailor policy changes to enhance existing programs for pollinators. Lastly, natural resource managers are often tasked with creating wildlife habitat, but typically lack the means to determine whether the new habitats are having a desired effect. This is especially true for pollinator plantings, which cost additional time and money to establish relative to more general conservation grassland plantings.

Our objective was to quantify the variation in floral resources among multiple categories of grasslands in the PPR from 2015 to 2018. We considered the forage value for pollinators of three major classes of grasslands: those specifically seeded to provide pollinator 
habitat ("Engineered Pollinator Habitat"), those that provide conservation cover not specific to pollinators ("Conservation Grassland"), and those that support a range of other uses ("General Grassland"). Specifically, we quantified floral resources on (1) private grasslands enrolled in pollinator habitat conservation programs including the CRP Conservation Practice 42-Pollinator Habitat and the Bee and Butterfly Habitat Fund (Engineered Pollinator Habitat); (2) private grasslands enrolled in the USDA Conservation Reserve Program (excluding those participating in $\mathrm{CP}-42$ ) and the USDA Environmental Quality Incentives Program, and public grasslands managed as wildlife habitat, including U.S. Fish and Wildlife Waterfowl Production Areas and state-owned wildlife management areas (Conservation Grassland); and (3) private grasslands used for pasture, haying, or idle prairie, and roadside ditches used for drainage control (General Grassland). We surveyed floral cover along transects to test for differences in flower abundance, richness, and community composition across the three major grassland classes and quantified temporal patterns in native and non-native flowers. Because of the importance of private lands and private land conservation programs to pollinator forage, we also investigated the variability in floral abundance and richness among the individual private land categories within the three major classes. We then scaled the results from our transect surveys in the PPR study area to quantify the potential annual floral resource availability of each grassland category across the region.

\section{Methods}

\section{Study area}

Our study area coincided with the PPR in the United States and was bounded to the north, east, and south by the extent of the region within North Dakota, South Dakota, and Minnesota (see Mann 1974), and to the west by the Missouri River (Fig. 1a, b), as delineated by the Commission for Environmental Cooperation (2010). We situated plant transects in association with apiaries (locations where beekeepers place their honey bee colonies) that were part of a concurrent multi-year study examining the impacts of land use/cover on honey bee colony health, productivity, and survival (Smart et al. 2018). We selected plant transect locations to occur within a 4.8-km radius of 38 study apiaries located in the PPR. Although honey bees can travel twice this distance, they are more likely to travel shorter distances if adequate forage is available (e.g., Ribbands 1951). Therefore, we selected a mid-range distance to demarcate potential forage areas around apiaries. We defined grassland/pasture as privately owned land that was not enrolled in a federal conservation program and where the dominant cover was grass. We defined roadside ditches as areas $>1 \mathrm{~m}$ and $<10 \mathrm{~m}$ from the edge of a paved or gravel road (e.g., Fig. 1d). For safety reasons, we did not conduct surveys along state or interstate highways.

Wildlife Management Areas (WMA) are owned and administered by the North Dakota Game and Fish Department and are managed for the production of vertebrate wildlife. South Dakota and Minnesota have their own versions of WMA; however, we did not encounter any of these lands in our study area transects and thus omitted state-owned wildlife areas in South Dakota and Minnesota from our analysis. Waterfowl Production Areas (WPA) are owned and administered by the U.S. Fish and Wildlife Service and are satellites of the National Wildlife Refuge system. They are primarily managed for waterfowl production. The CRP and EQIP are programs administered by the USDA that target private lands. Landowners enrolled in the CRP receive an annual rental payment from the USDA to take 


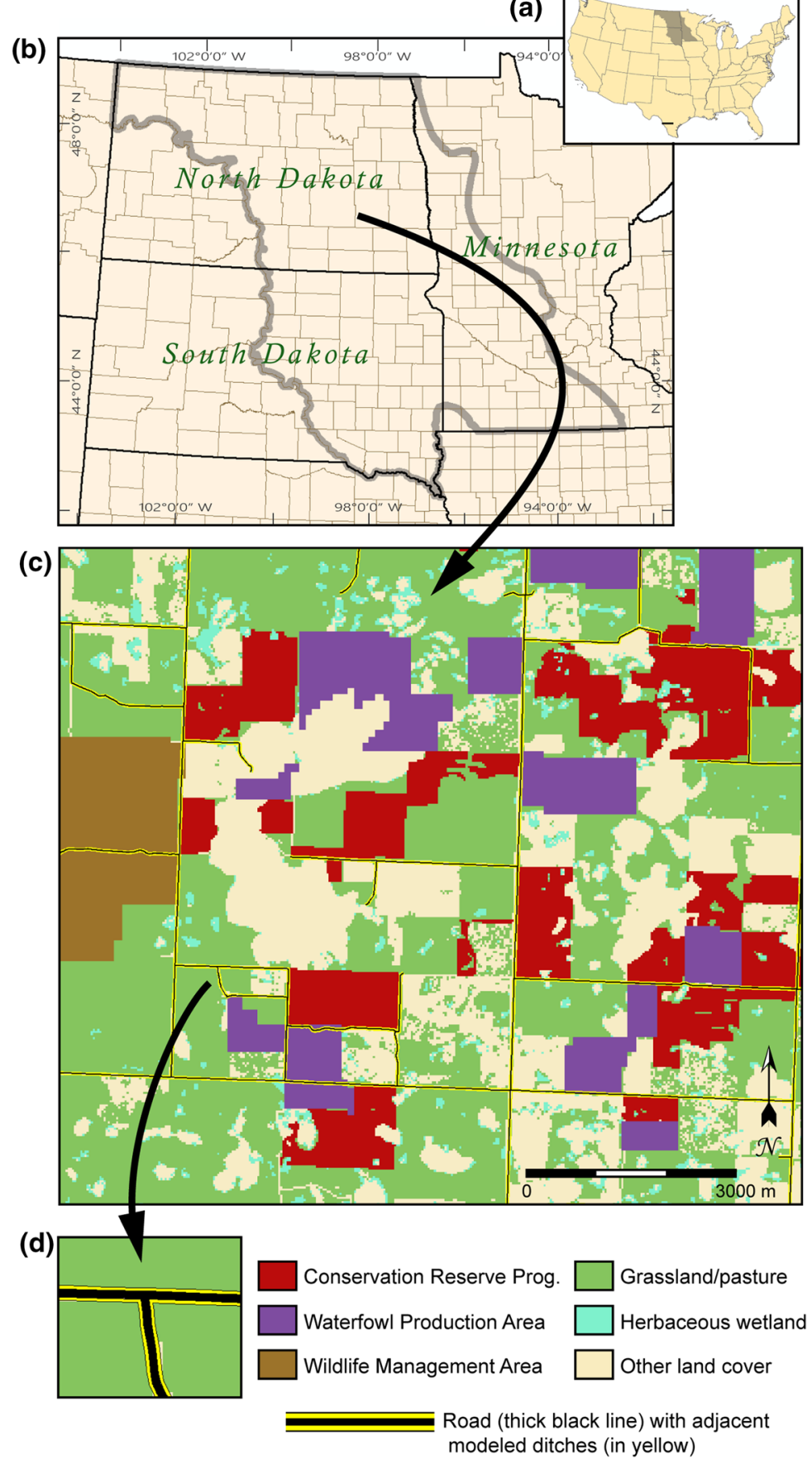

Fig. 1 Study area and example landscape near an apiary including the grassland categories we analyzed. The research was conducted in a the Prairie Pothole Region b within counties of the states of North Dakota, South Dakota, and Minnesota. Plant transects were surveyed on fields within a 4.8-km radius from study apiaries (Smart et al. 2018), and total area of each c land use category was quantified within the defined portion of the PPR, which included distinguishing $\mathbf{d}$ roadside ditches from adjacent land categories 
environmentally sensitive land out of crop production and establish a perennial cover. The EQIP provides landowners with financial assistance and technical support to implement conservation practices on their agricultural lands. The BBHF is a non-government organization that provides financial assistance for seed and technical support to landowners for establishing pollinator forage on lands previously in crop production (https://www.beean dbutterflyfund.org/).

The CRP contains numerous conservation practices that may be implemented based on landowner objectives and land characteristics (SI Table 1, and see https://www.fsa.usda. gov/programs-and-services/conservation-programs/index). Conservation Reserve Program practices have different seed mix options, and not all of the practices contain a forb component in the specified planting mix. Similarly, the EQIP also has multiple practices, but three practices commonly found in our region are Conservation Cover (EQIP-327), Forage and Biomass Planting (EQIP-512), and Range Planting (EQIP-550; and see https://www. nrcs.usda.gov/wps/portal/nrcs/main/national/programs/financial/eqip/).

\section{Floral transect surveys}

We conducted our sampling to be reflective of the distribution and amount of private and public land in the PPR. We obtained spatial records of public land areas from state geographic information system portals (North Dakota: https://gishubdata.nd.gov/; South Dakota: http://opendata2017-09-18t192802468z-sdbit.opendata.arcgis.com/; Minnesota: https://gisdata.mn.gov/) and worked with local USDA offices to determine where CRP and EQIP enrollments occurred. We overlaid the spatial data on private lands with the 2014 National Agricultural Statistics Service Cropland Data Layer (U.S. Department of Agriculture, National Agricultural Statistics Service 2018) to determine the distribution of grasslands intersecting private lands that were not enrolled in a federal conservation program. We then used a geographic information system to determine what public and private grasslands were within a $4.8-\mathrm{km}$ radius of our 38 research apiaries to identify private and public fields we could potentially survey for flowers. We obtained permission from landowners to conduct field sampling on private grasslands.

For each survey, two field technicians used a Geographic Positioning System to navigate to the randomly selected starting point. Technicians then established a $2 \mathrm{~m} \times 20 \mathrm{~m}$ transect, running north from the transect start location. Along roadside ditches, the transect ran parallel to the road. Transect boundaries were delineated with a meter tape across the center line and metal flags at the four corners. On each transect, technicians identified flowering plant taxa to species and quantified the flower abundance of each plant in bloom. Because of the potentially high numbers of flowers we could encounter in the field, we developed an index of flower abundance for use on all transects. Technicians counted the number of stems supporting one or more inflorescences and used this as an index of flower abundance (hereafter "floral stem abundance"). Although not a true census of the number of flowers per transect, our use of flowering stems provided a reliable index of flower abundance for comparisons across plant species, grassland categories, seasons, and years.

In 2015, we used a geographic information system to implement a stratified random selection of 906 transects for flower surveys in a subset of public and private grasslands. Grassland/pasture is, by far, the most extensive grassland category in the PPR, so to ensure that we sampled less abundant categories sufficiently for our analysis, we preferentially weighted the selection such that $40 \%$ of the transects were in CRP lands, $20 \%$ were in 
EQIP lands, $15 \%$ were in roadside ditches, $15 \%$ were in grassland/pasture, and $10 \%$ were in public (WMA and WPA) lands, with four additional transects conducted on BBHF lands as part of a parallel pilot project. In each of 2016 and 2017, we included 12 additional transects on private lands that were newly seeded with BBHF seed mixes (28 transects among all years). These BBHF transects represented a census of all BBHF sites available in the PPR at that time.

To the extent possible, we resampled the same transects in 2015 and 2016, however, some transect sites were inaccessible because of land conversion or our inability to contact landowners. When replacing these "lost" transect sites, we targeted lands enrolled in USDA conservation programs that had vegetation cover we assumed was of nutritional value to pollinators, such as CRP pollinator habitat (CP-42) or EQIP conservation cover (Practice 327), forage and biomass planting (Practice 512), and range planting (Practice 550). In 2017 and 2018, we reduced the number of transects by $60 \%$ and $40 \%$, respectively, because of labor limitations, including discontinuing all WPA transects. Due to the relative scarcity of some of the Engineered Pollinator Habitat and Conservation Grassland, we also selected transect sites for sampling that were beyond the $4.8-\mathrm{km}$ radius of our research apiaries, but still within the local landscape.

We surveyed 2547 transects over 4 years: 906 in 2015; 975 in 2016; 407 in 2017; and 259 in 2018 . We visited some transects all 4 years, whereas we visited other transects in only one or two of the study years. This hybrid design was employed because (1) some fields were not available for sampling until later years; (2) some fields were converted from grassland to row crop before we completed the study, and/or; (3) we were unsuccessful in obtaining permission to survey private land in certain years. The scope of our fieldwork was reduced in 2017 and 2018, which required us to eliminate approximately half and then two-thirds of our transects, respectively.

Whenever possible, each transect was surveyed three times per year: early season (June 16-July 15), mid-season (July 16-August 15), and late season (August 16-September 15) over the four years of the study. In certain cases, transects could not be surveyed three times per year because of weather or site accessibility. Across all years, our sampling design resulted in 7405 surveys among 2547 transects. Thus, our sampling effort was unequal across the three temporal replicates (SI Table 2). We defined each survey of a transect as an individual event; thus, the full complement of transect visits over the seasons and years of our study resulted in a dataset of 7405 surveys. We considered each of these survey incidents as statistically independent because sampling was carried out at random locations within each transect site (a field or roadside) and, more importantly, because of the dramatic changes in forb species that phenologically occurred over each growing season and among years.

\section{Analyses of floral survey data}

Prior to analysis, we grouped data from our transect surveys into three broad management classes: Engineered Pollinator Habitat (BBHF, CP-42), Conservation Grassland (CRP [excluding CP-42], EQIP, WMA, WPA), and General Grassland (non-conservation grassland/pasture, road ditches). We described the floral resource community available to pollinators by identifying the most abundant native and introduced flowering plants. We examined the relationships between the main effects of grassland class and time of season, and the response variables of floral stem abundance per transect and species richness per transect. We tested for an interaction between grassland class and season in our generalized 
linear mixed effect models and conducted Tukey contrasts to compare among main effect treatment groups (R Core Team 2020, package lme4). For both floral stem abundance and plant species richness responses, the data were highly zero-skewed, so we ran negative binomial generalized linear models. To control for annual fluctuation in flower abundance and richness, and transects located in the same field, we included both year and field as random effects. We visualized floral community composition differences between grassland classes and season of collection using principle coordinates analysis; furthermore, we statistically tested for differences in the community composition of grassland classes, season, and a grassland $\times$ season interaction using a permutational multivariate analysis of variance (PERMANOVA) with the adonis function of the $R$ package vegan (Oksanen et al. 2020). Because PERMANOVA can be sensitive to unbalanced study designs as well as groups with different dispersion, we combined individual transect surveys that occurred within the same sampled field.

\section{Upscaling survey results to the study region}

We obtained geospatial information from multiple sources to enable upscaling the field survey data for the grassland categories to the PPR study area. We compiled data on (1) CRP, (2) WMA, (3) WPA, (4) EQIP, (5) other grasslands (along with pasture land) not included in the first four categories, and (6) roadside ditches (e.g., see Fig. 1c, d). The CRP boundaries we used represented lands under contract in 2016, provided as digital polygons by the USDA, Farm Service Agency through a data-sharing agreement. The WMA data were digital polygons current as of 2018 that we acquired online for North Dakota (North Dakota Game and Fish Department 2018) and Minnesota (Minnesota Department of Natural Resources 2018). We did not survey Game Production Areas managed by South Dakota Game, Fish and Parks. We extracted WPA polygons from the Protected Areas Database of the United States, current as of 2016 (U.S. Geological Survey, Gap Analysis Program 2016). We obtained proprietary county-level statistics on EQIP participation from the USDA Natural Resources Conservation Service. For grasslands outside these conservation types we used the Cropland Data Layer representing land cover in 2017 (U.S. Department of Agriculture 2018), which we downloaded for North Dakota, South Dakota, and Minnesota in raster format at a 30-m spatial resolution. We used the Cropland Data Layer primarily to identify areas of grassland and pasture, but also to determine where roadside ditches (described further below) were likely to intersect cropland or other cover types that could provide potential additional acreage for pollinator habitat seed mixes.

To determine the total area in each land category, we compiled the data layers into a single raster map (30-m cell resolution). We lacked specific location data for the EQIP lands, so we subsequently estimated EQIP area mathematically (rather than spatially) by subtracting county EQIP total area from the total area of General Grassland cover in those counties (i.e., grasslands not in CRP, WMA, or WPA). In cases where only part of a county was contained within our study area, we prorated the EQIP area for the proportion of the county falling within the study area boundaries. For BBHF sites, we requested acreage statistics for our region directly from BBHF.

We knew of no mapped data for road ditches across our study area and therefore modeled the distribution of ditches based upon general guidance for two-lane road widths (e.g., see North Dakota Department of Transportation 2017; South Dakota Department of Transportation 2018; and Minnesota Department of Transportation 2012) and ditch widths (Minnesota Department of Transportation 2001), aligned with 
digital road vectors from a national transportation dataset (U.S. Geological Survey 2018). Using centerline road vectors, we "constructed" road polygons based on 12-foot $(3.66 \mathrm{~m})$ guidance (U.S. customary units) for widths for each lane outward from the centerlines. As two-lane roads comprise the vast majority of transportation routes in the predominantly rural landscapes of the Dakotas and Minnesota, we used a width of 24 feet $(7.32 \mathrm{~m})$. We then delineated 10 -foot $(3.01 \mathrm{~m})$ ditches along road edges, based upon an average width of ditches we measured from 20 transects in locations in the three states where we had conducted field studies. To estimate potential area in ditches that might support pollinator forage habitat, we intersected our modeled roadside ditches with cropland areas or other non-conservation land cover that might provide additional habitat (note that we excluded developed areas and open water from this estimate).

We quantified the total area in each of the grassland categories (road ditches, CRP, WMA, WPA, EQIP, BBHF, and non-conservation grassland/pasture) across the PPR study area. We then applied our estimates of flower abundance and species richness from the field transect surveys to the total regional area of each grassland category to estimate total regional area of floral resources and species richness contributed by the different grassland programs and practices in the study region.

\section{Results}

We observed 269 taxonomically distinct flowering plant species growing on the surveyed grassland categories, of which 196 species were classified as native and 73 were classified as introduced (U.S. Department of Agriculture 2020, SI Table 3). The most commonly encountered plant species were Medicago sativa, Melilotus officinalis, and Cirsium arvense, detected during 33\%,31\%, and $21 \%$ of transect sampling events $(n=7405)$, respectively (Table 1$)$. The most commonly encountered native plants were Rudbeckia hirta $(566 / 7405=8 \%$ of transects), followed by Heliopsis helianthoides (6\%), Symphyotrichum ericoides (6\%), and Ratibida columnifera (6\%).

Among all surveys, $81 \%$ of flowering stems counted were introduced species (Fig. 2). The greatest overall contributor of floral abundance was Medicago sativa, making up $48 \%$ of the flower counts, followed by Melilotus officinalis (13\%) and Melilotus alba (4\%). The native plants with the greatest flower abundances were Rudbeckia hirta (2\% of observed flower abundance per transect), Heliopsis helianthoides (1.5\%), and Symphyotrichum ericoides (1.4\%). Among the surveyed categories, Conservation Grassland had the highest proportion of introduced taxa by total flower abundance among years (83\%), followed by both Engineered Pollinator Habitat and General Grassland (each with 79\%). However, when assessing the total number of taxa observed, all three major grassland classes had a higher percentage of native species relative to introduced species (General Grassland $=74 \%$, Conservation Grassland $=72 \%$, Engineered Pollinator Habitat $=64 \%$ ).

\section{Floral resources by major land class and season}

We detected a significant interaction between grassland category and season with respect to the mean floral stem abundance per transect. Flowering stem abundance on Engineered 
Table 1 Top 10 flowering plants, their indigenous status, and mean flower abundance per transect for Engineered Pollinator Habitat, Conservation Grassland, and General Grassland in the Prairie Pothole Region of the United States

\begin{tabular}{|c|c|c|c|}
\hline Major Grassland Class & Plant species & Status & $\begin{array}{l}\text { Mean floral stem } \\
\text { abundance per } \\
\text { transect }\end{array}$ \\
\hline Engineered & Medicago sativa & Introduced & 176 \\
\hline Pollinator & Melilotus officinalis & Introduced & 30 \\
\hline \multirow[t]{8}{*}{ Habitat $^{\mathrm{a}}$} & Heliopsis helianthoides & Native & 13 \\
\hline & Rudbeckia hirta & Native & 11 \\
\hline & Bassia scoparia & Introduced & 7 \\
\hline & Cirsium arvense & Introduced & 6 \\
\hline & Dalea purpurea & Native & 5 \\
\hline & Sonchus arvensis & Introduced & 5 \\
\hline & Artemisia absinthium & Introduced & 5 \\
\hline & Conyza canadensis & Native & 5 \\
\hline Conservation & Medicago sativa & Introduced & 61 \\
\hline \multirow[t]{9}{*}{ Grassland $^{\mathrm{b}}$} & Melilotus officinalis & Introduced & 15 \\
\hline & Melilotus alba & Introduced & 8 \\
\hline & Cirsium arvense & Introduced & 4 \\
\hline & Sonchus arvensis & Introduced & 3 \\
\hline & Rudbeckia hirta & Native & 2 \\
\hline & Medicago lupulina & Introduced & 2 \\
\hline & Chenopodium album & Introduced & 2 \\
\hline & Helianthus maximiliani & Native & 2 \\
\hline & Monarda fistulosa & Native & 2 \\
\hline General & Medicago sativa & Introduced & 34 \\
\hline \multirow[t]{9}{*}{ Grassland $^{\mathrm{c}}$} & Melilotus officinalis & Introduced & 19 \\
\hline & Medicago lupulina & Introduced & 7 \\
\hline & Trifolium pratense & Introduced & 3 \\
\hline & Symphyotrichum ericoides & Native & 3 \\
\hline & Melilotus alba & Introduced & 3 \\
\hline & Ambrosia artemisiifolia & Native & 3 \\
\hline & Convolvulus arvensis & Introduced & 3 \\
\hline & Trifolium repens & Introduced & 2 \\
\hline & Cirsium arvense & Introduced & 2 \\
\hline
\end{tabular}

Flower stem abundance data for the original grassland categories, including among Conservation Reserve Program (CRP) and Environmental Quality Incentives Program (EQIP) practices, are provided in SI Table 3 ${ }^{a}$ Included Bee and Butterfly Habitat Fund and the CRP Conservation Practice 42-Pollinator Habitat

${ }^{b}$ Abundance of flowering plants blooming on 16 practices within the CRP, three practices within the EQIP, Wildlife Management Areas, and Waterfowl Production Areas

${ }^{\mathrm{c}}$ Included road ditches, non-conservation grassland, and pastures

Pollinator Habitat was significantly greater than on the other two grassland classes examined in all three seasons (Fig. 3; Early season: Engineered Pollinator Habitat vs. Conservation Grassland: $z=-3.05, p=0.05$; Engineered Pollinator Habitat vs. General Grassland: $z=4.72, p=0.0001$; Conservation Grassland vs. General Grassland: $z=2.68, p=0.16$; 


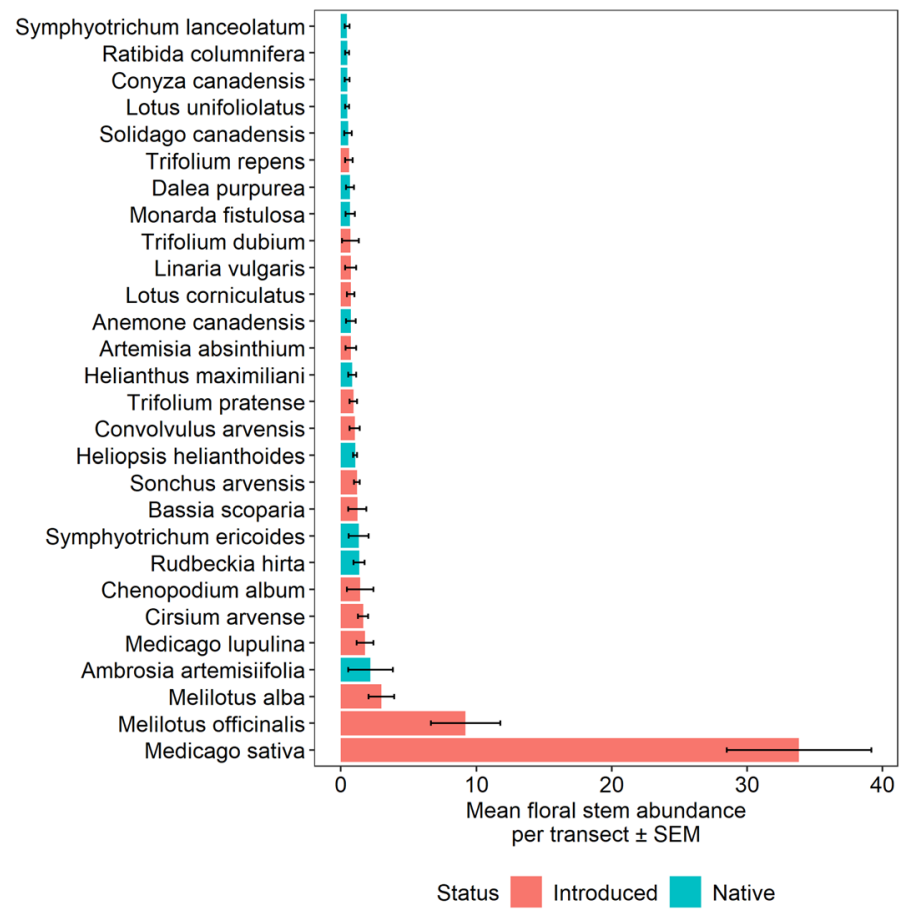

Fig. 2 Mean floral stem abundance per transect in the Prairie Pothole Region of the United States among all studied grassland categories, surveys, and years (2015-2018). Errors bars represent the standard error of the mean (SEM). Color depicts indigenous status (USDA PLANTS database, https://plants.sc.egov.usda.gov/ java). We depict only plants that averaged at least 0.5 flowering stems per transect per year. The entire list of 269 taxa by grassland category, conservation practice type, and indigenous status is shown in SI Table 3

Mid-season: Engineered Pollinator Habitat vs. Conservation Grassland: $z=-1.56$, $p=0.83$; Engineered Pollinator Habitat vs. General Grassland: $z=3.86, p=0.004$; Conservation Grassland vs. General Grassland: $z=3.55, p=0.01$; Late season: Engineered Pollinator Habitat vs. Conservation Grassland: $z=-0.15, p=1.0$; Engineered Pollinator Habitat vs. General Grassland: $z=1.18, p=0.96$; Conservation Grassland vs. General Grassland: $z=1.58, p=0.82$ ). In general, differences in flowering stem abundance were most pronounced in the early season, with all land categories having nearly similar flowering stem abundances by the late season. Flowering stem abundance was highest in the early season $(\bar{x}=195 \pm 8$ SEM flowering stems per transect) and lowest in the late season $(\bar{x}$ $=87 \pm 4$ SEM), with the mid-season being of intermediate stem abundance $(\bar{x}=139 \pm 6$ SEM). Introduced flowers were more abundant than native flowers across the three major classes of grassland we surveyed, and introduced flowers were most abundant during the early season, followed by the mid- and late seasons, respectively (SI Fig 1).

Mean plant species richness per transect (range 2.2-5.9 species) varied over grassland class by season (Fig. 4, Early season: Engineered Pollinator Habitat vs. Conservation Grassland: $z=-5.1, p<0.0001$; Engineered Pollinator Habitat vs. General Grassland: $z=5.39, p=0.0001$; Conservation Grassland vs. General Grassland: $z=0.66, p=1.0$; Midseason: Engineered Pollinator Habitat vs. Conservation Grassland: $z=-3.66, p=0.008$; Engineered Pollinator Habitat vs. General Grassland: $z=5.54, p<0.0001$; Conservation 


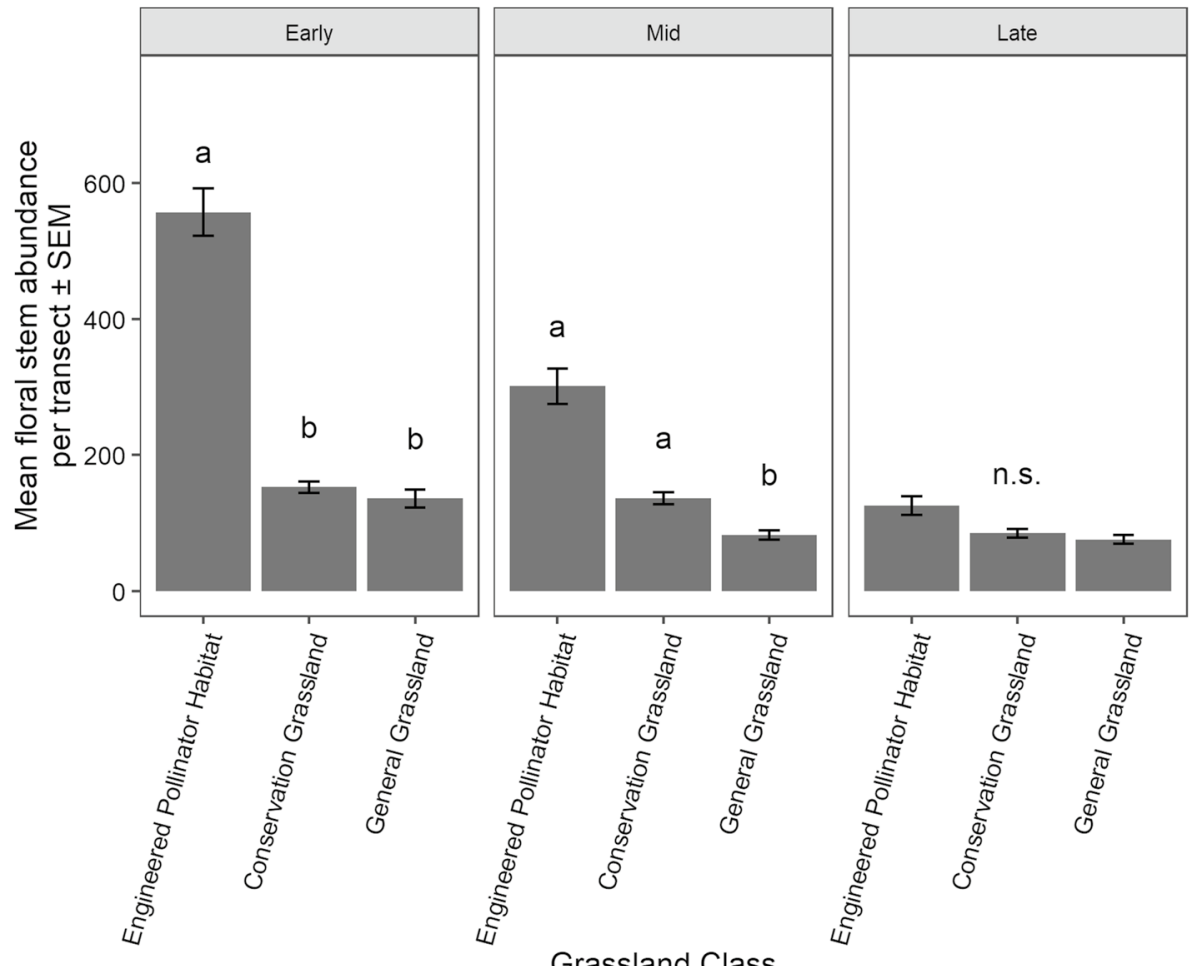

Fig. 3 Floral stem abundance per transect among the surveyed major grassland classes in the Prairie Pothole Region of the United States. Letters denote significant differences $(\alpha \leq 0.05)$ among the mean floral stem abundances of the classes within each season (early, mid-, and late) and errors bars represent the standard error of the mean. Engineered Pollinator Habitat includes transects surveyed on lands participating in the Conservation Reserve Program Conservation Practice-42 (Pollinator Habitat) and the Bee and Butterfly Habitat Fund. Conservation Grassland includes transects surveyed on lands participating in the Conservation Reserve Program (non-pollinator habitat practices) or the Environmental Quality Incentives Program, or lands managed as Wildlife Management Areas or Waterfowl Production Areas. General Grassland includes transects surveyed on all other (non-conservation) grasslands, pastures, and road ditches. A finer-scale breakdown of the grassland categories within these three major classes and flower abundance data are shown in SI Fig. 2. SEM standard error of the mean. n.s. not statistically significant

Grassland vs. General Grassland: $z=2.84, p=0.10$; Late season: Engineered Pollinator Habitat vs. Conservation Grassland: $z=-2.53, p=0.22$; Engineered Pollinator Habitat vs. General Grassland: $z=3.14, p=0.04$; Conservation Grassland vs. General Grassland: $z=0.98, p=0.99$ ). Native and introduced species richness among the three major grassland classes by season are distinguished in SI Fig 3.

Floral community composition was not different among grassland classes (SI Fig 5; $S S=0.80$, Mean $S S=0.40, F=1.17, p=0.23$ ). There was some variance in community composition between seasons ( $S S=4.40$, Mean $S S=2.20, F=6.42, p<0.01$ ), but this was dependent on an interactive grassland class $\times$ season factor $(S S=2.02$, Mean $S S=0.51$, $F=1.48, p=0.02$ ). 


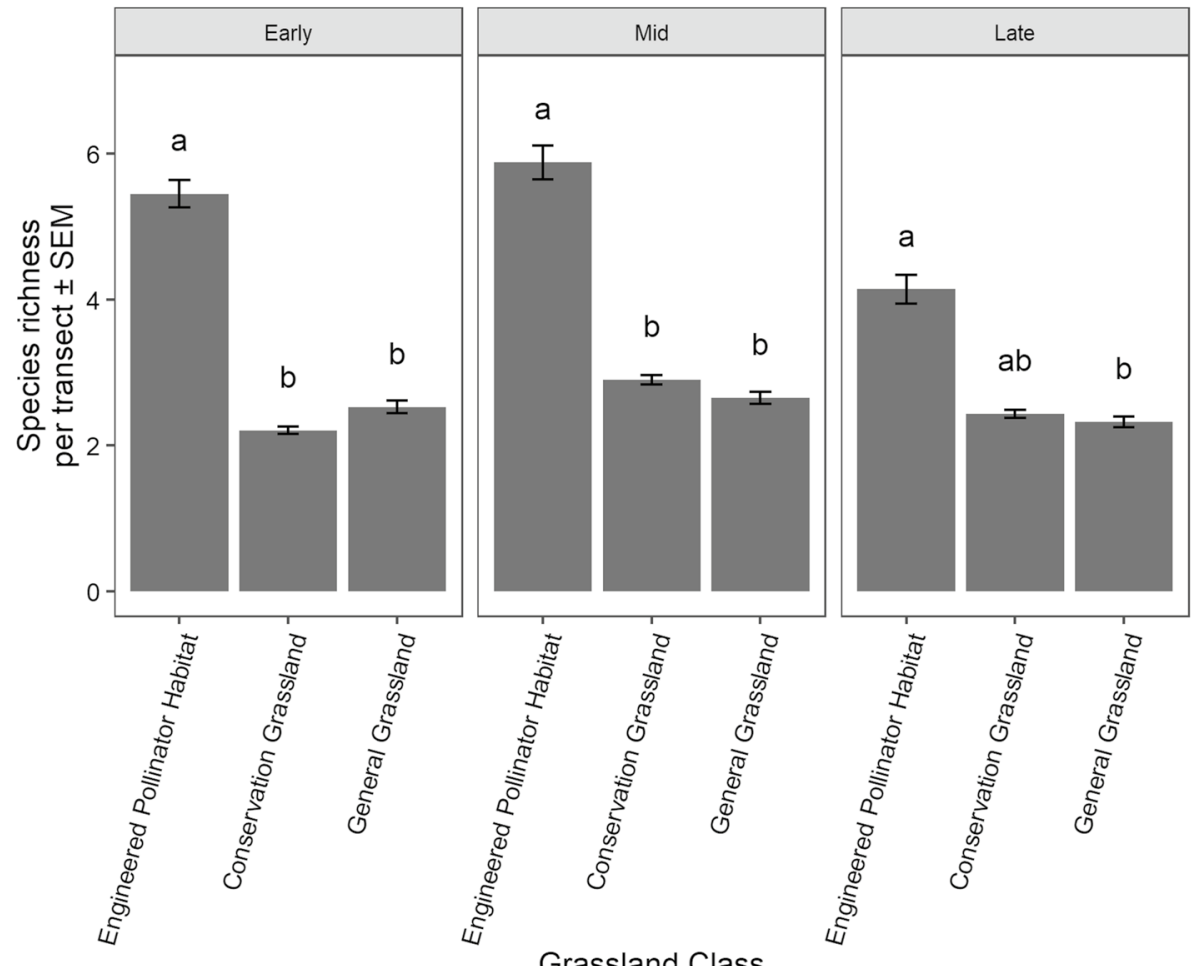

Fig. 4 Floral species richness per transect among the three major classes of grassland in the Prairie Pothole Region of the United States. Letters denote significant differences $(\alpha \leq 0.05)$ in transect-level richness among the three classes and errors bars represent the standard error of the mean (SEM). Engineered Pollinator Habitat includes transects surveyed on lands participating in the Conservation Reserve Program Conservation Practice-42 (Pollinator Habitat) and the Bee and Butterfly Habitat Fund. Conservation Grassland includes transects surveyed on lands participating in the Conservation Reserve Program (non-pollinator habitat) and the Environmental Quality Incentives Program or lands managed as Wildlife Management Areas and Waterfowl Production Areas. General Grassland includes transects surveyed on all other (nonconservation) grasslands, pastures, and road ditches. Data were log-transformed prior to analysis, but raw data are depicted in the figure. Finer-scale breakdown of the grassland categories and flower richness data within the three major grassland classes (land categories) by season are distinguished in SI Fig. 4

\section{Flower abundance and richness among land conservation practices on private lands}

Our analysis of pollinator forage indicated significant variation in resource availability across grassland classes (Figs. 3 and 4). We further investigated variation in resource availability on private lands by quantifying flower abundance and richness of 12 CRP and 3 EQIP practices and the Bee and Butterfly Habitat Fund (SI Fig 6). As expected, there was variation in flower abundance and species richness across multiple conservation practices. Conservation practices specifically designed as Engineered Pollinator Habitat (i.e., CP-42 and Bee and Butterfly Habitat Fund) had among the highest flower abundance and richness. 


\section{Landscape flower abundance}

We estimated floral resource abundance to be on the order of 213 billion flowering stems annually, at a rate of approximately 25,000 per hectare, across the grassland categories we surveyed (Table 2). Engineered Pollinator Habitat in our region had the highest flower abundance among grassland categories, but also the smallest spatial footprint (Fig. 5; Table 2), contributing just $0.1 \%$ of the estimated flower abundance in our region. The majority of flowers in the PPR landscape were contributed by the grassland/pasture category of the General Grassland class (Table 2), even though this land category harbored less than half as many flowers per transect as Engineered Pollinator Habitat. For example, BBHF had the greatest flower abundance per transect (417 flowering stems per transect), but the smallest regional footprint among all land categories ( 880 hectares, Fig. 5), thereby limiting its regional flower contribution (estimated 91 million flowering stems; Table 2; Fig. 5). In comparison with BBHF, CP-42 (CRP Pollinator Habitat) had relatively lower average flower abundance (292 flowering stems per transect), but nearly double the total number of flowers regionally (166 million flowering stems, Table 2) because of the greater total area of CP-42 (2274 hectares). Grassland/pasture, the dominant grassland category included in our study, contained approximately 3.9 and 2.7 times less flower abundance

Table 2 Area of surveyed land categories, estimated number of flowering stems, and estimated area of flowering plants within the Prairie Pothole Region of the United States study area

\begin{tabular}{lrllc}
\hline $\begin{array}{l}\text { Major grassland classes } \\
\text { and associated categories }\end{array}$ & $\begin{array}{c}\text { Area (ha) in } \\
\text { study region }\end{array}$ & $\begin{array}{l}\text { Mean flower } \\
\text { abundance per } \\
\text { transect }^{4}\end{array}$ & $\begin{array}{l}\text { Mean flower } \\
\text { abundance } \\
\text { per ha }\end{array}$ & $\begin{array}{l}\text { Estimated average flower } \\
\text { abundance in study region } \\
\text { annually }\left(\times 10^{6}\right)\end{array}$ \\
\hline $\begin{array}{l}\text { Engineered Pollinator } \\
\text { Habitat }\end{array}$ & 3154 & & & \\
BBHF $^{\text {a }}$ & 880 & 417 & 104,250 & 91 \\
CP-42 $_{\text {Conservation Grassland }}$ & $1,534,022$ & & 72,250 & 166 \\
CRP $^{b}$ (non CP-42) & $1,035,726$ & 105 & & \\
EQIP & 75,296 & 175 & 26,250 & 27,188 \\
WMA & 161,000 & 90 & 43,750 & 3294 \\
WPA & 262,000 & 78 & 22,500 & 3623 \\
General Grassland & $6,742,500$ & & 19,500 & 5109 \\
Roadside Ditch & 242,500 & 89 & & 5396 \\
Grass/Pasture & $6,500,000$ & 107 & 22,250 & 173,875 \\
\hline
\end{tabular}

$B B H F$ Bee and Butterfly Habitat Fund; $C P-42$ Conservation Practice 42 Pollinator Habitat; $C R P$ Conservation Reserve Program; EQIP Environmental Quality Incentives Program; WMA Wildlife Management Area; WPA Waterfowl Production Area

${ }^{\text {a } T o t a l ~ a r e a ~ o f ~ B B H F ~ w a s ~ d e t e r m i n e d ~ a t ~ t h e ~ s t a t e ~ l e v e l ~ o n l y, ~ f r o m ~ N o r t h ~ D a k o t a, ~ S o u t h ~ D a k o t a, ~ a n d ~ M i n n e-~}$ sota, and therefore some area may fall outside the PPR

${ }^{b}$ These values represent the total areas of all CRP in the study region, a subset of which were surveyed in the current study

${ }^{\mathrm{c}}$ Areas of individual EQIP practices (practices 327, 512, and 550) were provided to us at the county level only; we included areas of those EQIP practices for all counties that at least partially fell within the PPR

${ }^{4}$ Transect dimensions: $2 \mathrm{~m} \times 20 \mathrm{~m}=0.004$ ha 


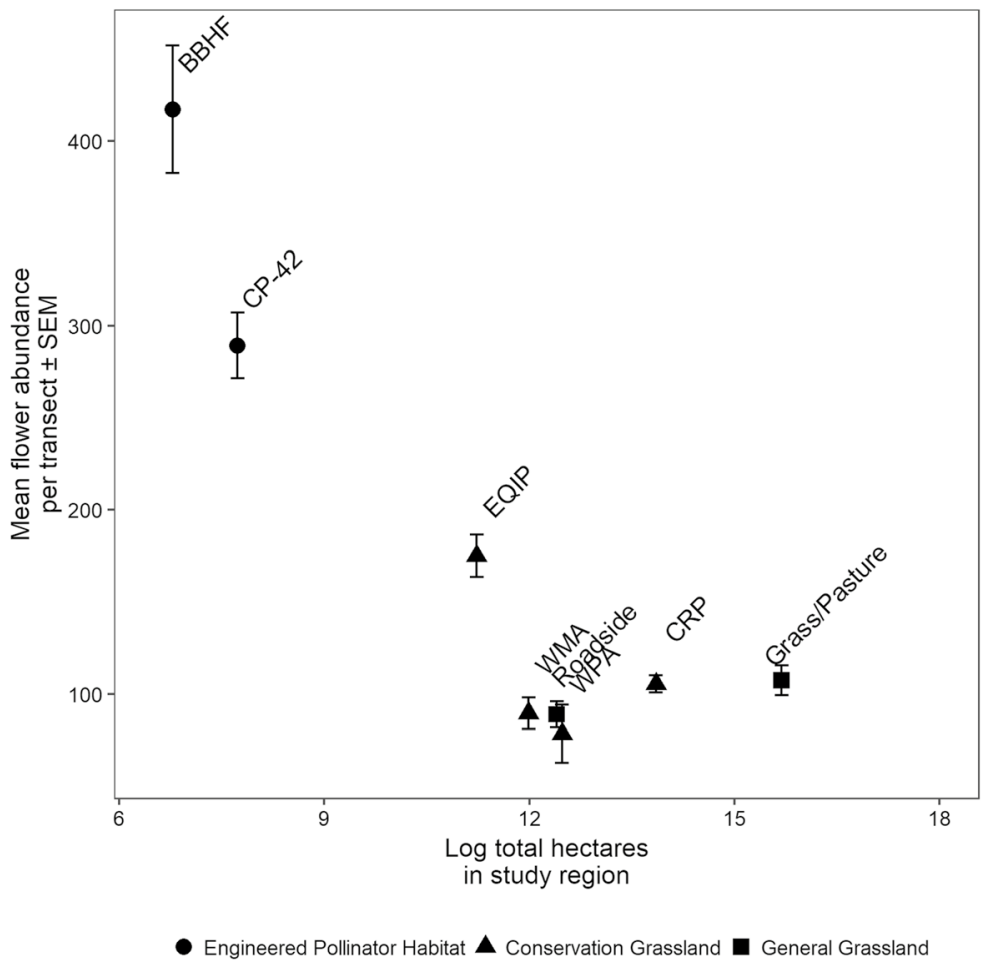

Fig. 5 Total land area and estimated flower abundance per transect among surveyed grassland categories in the Prairie Pothole Region of the United States. Total land area is log transformed to better visually display the results. $B B H F$ Bee and Butterfly Habitat Fund; $C P-42$ Conservation Practice 42 Pollinator Habitat; $C R P$ Conservation Reserve Program; EQIP Environmental Quality Incentives Program; WMA Wildlife Management Area; WPA Waterfowl Production Area; SEM standard error of the mean. Shapes denote major grassland classes surveyed

per transect than BBHF and CP-42, respectively, but nevertheless contributed 1,000 times more flowers in the region annually than did Engineered Pollinator Habitat.

\section{Discussion}

Understanding the role of grasslands managed for different purposes in shaping pollinator habitat in agroecosystems is important for achieving national goals for pollinator health (Pollinator Health Task Force 2015). This is particularly true in the PPR, where agricultural expansion has largely eliminated native and semi-native grasslands (Wright and Wimberly 2013). To mitigate extensive conversion of grasslands to cropland, multiple government agencies and private interest groups have made concerted efforts in recent years to enhance the value of existing conservation covers for pollinators and to develop seed mixes specifically designed to benefit bees. Our work represents the first regional, multiyear assessment of flower abundance, richness, and species composition that quantifies the outcomes from those efforts to improve pollinator forage at the local scale, estimates their impact across the current regional landscape, and suggests a way forward to enhance their 
impact. Our data provide evidence that despite similar overall floral composition, not all grasslands offer similar floral abundance or richness for pollinators, and we show that the floral resources within patches change over a growing season. Our data demonstrate that Engineered Pollinator Habitat contributes to a greater abundance and richness of flowering plants per unit area, particularly in the early season, than do grasslands managed for other purposes, but the overall spatial footprint of pollinator plantings remains small in the PPR and their flora are not compositionally different from other land-covers when considered at a broad scale. Thus, results from our study suggest a vast, but currently underutilized, potential for expanding pollinator habitat by augmenting grasslands managed for a variety of purposes (such as the various categories of Conservation Grassland and General Grassland that we studied) with pollinator-utilized forbs.

\section{Landscape flower abundance}

Our regional estimates of flower abundance and spatial coverage demonstrate existing contrasts between Engineered Pollinator Habitat, Conservation Grasslands, and General Grasslands. Whereas flower abundance was significantly higher in grassland categories of Engineered Pollinator Habitat, particularly in the early season, than in grassland categories of other major classes, the regional contribution of pollinator habitat to total flower abundance was relatively small. Conversely, categories of General Grassland had among the lowest flower abundances per transect, but contributed the greatest flower abundance when up-scaled spatially across the region. Our results can be applied to estimate changes in flower abundance from different scenarios of land use change. For example, Wright and Wimberly (2013) estimated 530,000 ha of grassland were lost from 2006 to 2011 in the Great Plains. Based on our flowering stem counts on grasslands, loss of this magnitude could have resulted in an estimated loss of 13 billion flowers annually. Although the loss of an individual patch of grassland may not have an appreciable impact on the availability of pollinator forage when viewed in isolation, such local changes add up to large-scale losses of grasslands regionally, as has been observed in recent years and likely has resulted in a considerable reduction in flowers across the region. Similarly, Otto et al. (2018) estimated 130,000 ha of CRP land within $1.6 \mathrm{~km}$ of honey bee apiaries in North Dakota and South Dakota were converted to corn or soybeans from 2006 to 2012. Our estimates suggest this conversion in the Dakotas would have meant the loss of 3.4 billion flowering stems annually across the top-two honey-producing states in the nation (U.S. Department of Agriculture 2019).

Our results highlight how the patchwork of grasslands managed for different purposes culminates in a landscape mosaic of varied forage and habitat resources for wild and managed pollinators. Whereas an EQIP forage and biomass planting consisting of early season Medicago sativa may not support wild bees with specialized forage diets, this planting may be used by honey bees to make a valuable honey crop (Gallant et al. 2014; Otto et al. 2017). Similarly, a CRP CP-42 (Pollinator Habitat) planting with high floral richness may not be highly visited by honey bees in mid-July, but such patches will provide diverse native plants to support wild pollinators, such as native bees (Otto et al. 2017). Having diverse grasslands within a single landscape can support both a diverse wild pollinator community and a robust beekeeping industry (Evans et al. 2018; Darby et al. 2020; Lane et al. 2020). We did not observe compositionally different floral communities between our broad grassland classes; however, this is likely a result of sites with highly diverse floral assemblages still having high numbers of common, broadly-distributed species like Medicago sativa 
and Melilotus spp. Conserving and enhancing this mosaic of pollinator forage lands may require the involvement of public and private land stewards and the strengthening of land conservation programs in the PPR. Given that $>90 \%$ of the total land area among the three surveyed states is privately owned, substantially improving forage for pollinators will likely require a concerted effort on the part of private landowners and those stakeholders who promote private land conservation (Samson and Knopf 1994).

Our findings fit within the broader literature highlighting the tremendous potential of multiple grassland categories to provide additional benefits to managed and native pollinators through altered management or restoration (e.g., Orford et al. 2016; Sexton and Emery 2020). Although many grasslands cannot be managed for the sole objective of providing pollinator habitat, there are cost-effective management actions that could be undertaken on all grasslands to provide significant regional impact (e.g., Senapathi et al. 2017). The road ditches, pastures, and non-conservation grasslands we surveyed (General Grassland) had limited flower abundance per transect, but were so extensive in area that they accounted for a majority of the floral resources. Small management actions that could be implemented across a large proportion of this general land category would have a profound impact on regional flower abundance. For example, patch burn grazing and altered grazing regimes that reduce grazing severity have been identified as management activities that result in the restoration and maintenance of plant communities and appropriate wildlife and pollinator habitat (Sjodin 2007; Black et al. 2011; Scasta et al. 2016). Were these techniques to be implemented across grasslands in the PPR, the impact of such management actions could be enormous. The site-specific effects of altered grazing may seem relatively modest at the local scale, but the impact would be significant as a regional, collective effort. Road ditches offer another opportunity where slightly altered management practices have the potential to enhance pollinator forage across 242,500 ha in the PPR (Hopwood et al. 2015; Pengyao et al. 2020; Phillips et al. 2020). Although not explicitly quantified in our study, we observed that mowing greatly reduced the availability of flowers in road ditches, particularly after July. Delaying or reduced frequency of mowing has been shown to benefit pollinators (Hudewenz et al. 2012; Buri et al. 2014) and would not only increase the forage value of road ditches for bees, but may also save money for local governments in areas where tall vegetation does not present safety concerns.

The CRP was originally implemented to reduce soil erosion on environmentally sensitive farmland. Researchers have documented numerous, additional ecosystem services provided by the CRP (Gleason et al. 2011; Johnson et al. 2016; Ricigliano et al. 2019), and in our study we found the contribution to pollinator forage from different CRP practices was highly varied. There are multiple options that natural resource managers could consider to elevate the overall pollinator value of CRP lands, such as increasing the forb-to-grass seed ratio and including additional forb species in more traditional grass mixes. Our data showed that Engineered Pollinator Habitat (i.e., BBHF and CP-42) had the highest flower abundance during portions of the growing season, but lowest regional impact due to low total acreage. Establishing and maintaining high forb diversity plantings takes time and considerable management, and, as evidenced by our results, may not result in compositionally different grasslands despite changes in floral richness or abundance. Furthermore, the cost of the seed mix often is higher than the cost of traditional grassland plantings. These factors combined may make pollinator plantings less attractive to landowners interested in enrolling large swaths of land. To address this issue, the USDA offers considerable cost-sharing to landowners enrolling in $\mathrm{CP}-42$ Pollinator Habitat in addition to annual land rental payments, and the BBHF offers free seed to its enrollees. Both entities offer technical assistance to landowners for vegetation establishment and management. Ultimately, 
increasing the regional impact of Engineered Pollinator Habitat may require greater landowner participation through cost-sharing and subsidizing, or a shift in land ethic towards conservation, but our data show these lands are providing more floral resources for bees than other land categories in our region.

Our estimates of flower abundance are lower than the actual abundance of flowers in the landscape because (1) we did not survey all categories of land cover, such as National Wildlife Refuges, Forest Service lands, and areas containing flowering trees and shrubs, and (2) we quantified stems supporting one or more inflorescences, rather than counting individual inflorescences per stem. A number of land covers that may provide forage for pollinators were omitted from this study. We did not collect data from National Grasslands (U.S. Forest Service), Bureau of Land Management lands, state school lands, power line rights-of-way, ditches along railroad tracks, wetland margins, field edges, public parks, and urban areas. We also did not sample within mass-flowering crops such as alfalfa, canola, and sunflower fields that serve as ephemeral, pulsed sources of pollen and nectar, particularly for honey bees (e.g., Westphal et al. 2003; Decourtye et al. 2010). We focused on grasslands that were within the flight range of honey bees from target apiaries in the PPR. Emerging research suggests PPR wetlands and the surrounding terrestrial buffer zones are an under-studied and under-valued contributor to supporting the life histories of managed and wild pollinators (Evans et al. 2018; Vickruck et al. 2019). The Waterfowl Production Areas included in our study had limited floral resources for bees. These lands have traditionally been managed by the U.S. Fish and Wildlife Service as nesting cover for waterfowl, but our study suggests there is ample opportunity to add pollinator value to these lands.

\section{Temporal variation in flower abundance and richness}

Among all surveyed grassland categories, we found the highest flower abundances occurred early in the growing season (June 15-July 15), followed by the mid- and late seasons, respectively. We did not conduct flower surveys prior to June 15 because of the near absence of herbaceous flowers in the study region at that time. Nevertheless, May and early June are important for managed honey bee colonies and native, emerging queen bumble bees (Bombus spp.) that require dietary supplementation or access to floral resources very early in the season to initiate colony growth (Rotheray et al. 2017). Aside from forbs, flowers from woody plants and shrubs provide pollen and nectar for early-season bees during May and the beginning of June. Indeed, pollen from woody plants is commonly collected by honey bees during this time period in the region (Smart et al. 2017). Although we did conduct surveys in CRP practices planted with woody plants, we did not encounter many flowering species because they often were past bloom at the time of the survey. Such woody blooms are not distributed evenly in our region, being primarily restricted to field borders, shelterbelts, and riparian areas. Expanding our research to include woody plants in April and May would provide a better indication of resources available for bees at the beginning of the growing season and may provide insight into whether recent removal of woody shelterbelts in the PPR is impacting pollinators (Schaefer et al. 1987; Burke et al. 2019). Likewise, though we detected changes in floral resources across the season the species measured may not necessarily reflect the resources used or preferred by managed or native bees at each point throughout the season. Although woody plants historically were limited primarily to riparian areas in the PPR, they are nevertheless associated with species richness of wild bees and other wildlife (Yahner 1983; Haas 1995; Evans et al. 2018). 
The peak flower abundance we observed throughout mid-July coincides with an annual period of tremendous population growth within honey bee colonies and increased rate of honey production. Beekeepers managing approximately one million colonies across the region take advantage of this phenological pattern to prepare and position their honey bee colonies to maximize honey production (U.S. Department of Agriculture, National Agricultural Statistics Service 2019). The main regional nectar flows result from the blooms of sweet clover (Melilotus spp.) and alfalfa (Medicago sativa) beginning in mid-June and potentially lasting through September. We observed that after flower abundance peaked in July there was a decline in abundance and richness throughout the late summer and fall. This time period is known to coincide with the emergence of many native bee species, production of bumble bee males and gynes, honey bee colony production of overwintering workers, and monarch butterflies preparing to migrate south. Therefore, providing floral resources in the late summer and early fall will support the health of the adult bees that will survive the overwintering period (Mattila and Otis 2007) and help fuel the monarch butterfly migration (Brower et al. 2006). Research has shown that diverse pollen diets of fall bees support nutritional and immune system function and are directly tied to colony overwintering survival (Smart et al. 2016; Alaux et al. 2017).

Our study provides managers with information about specific periods within the growing season when floral resources are most limited for pollinators. These periods could be targeted for floral resource enhancement, particularly for conservation programs and practices where flowers are limited at the beginning of the growing season (prior to our period of sampling when few foraging resources existed) and at the latter part of the season. Designing seed mixes that provide forage for bees can be logistically challenging and information on plants that provide known benefits to bees is often unavailable. Quantifying bee utilization and preference of flowers was beyond the scope of our research but is important to consider when designing seed mixes (Williams et al. 2015; Simanonok and Otto 2020). Although planting mixes will need to be tailored to fit site-specific objectives, decision-support tools have been developed to assist natural resource managers in developing pollinator seed mixes (Otto et al. 2017; M'Gonigle et al. 2017). For example, Otto et al. (2017) demonstrated how publicly available, plant-pollinator interaction data can be used to design cost-effective seed mixes for honey bees and native bees under alternative management objectives.

\section{Flower indigenous status}

The ecological and economic implications of non-native species in natural and semi-natural systems is an important area of research (Schlaepfer et al. 2011; Bretagnolle and Gaba 2015). Our quantification of flowers in the working landscape of the PPR provides natural resource managers with information on the abundance of non-native and potentially invasive plants in the region. We define "non-native" as a species originating from somewhere outside the United States and "invasive" as a prolific species with the propensity to cause ecologic or economic harm. Across all grassland categories we surveyed, non-native plant species represented $81 \%$ of all flowers. Melilotus officinalis, M. alba, and Medicago sativa, all non-native species, were the most abundant forbs across our study and often are targeted by honey bees for pollen and nectar collection (Smart et al. 2017; Otto et al. 2017). Nonnative, invasive weeds such as Artemisia absinthium, Cirsium arvense, Euphorbia escula, and Sonchus arvensis, were also highly abundant on many of our transects. These highly abundant non-native species are likely a strong contributor to why floral communities are 
relatively similar across grassland classes. Furthermore, these species can cause considerable ecological damage and require significant investment to control. It is important to note, however, that weedy species are nonetheless important forage for both wild bees and honey bees (Bretagnolle and Gaba 2015; Smart et al. 2017). Although eliminating weeds in agroecosystems is a goal of natural resource managers, the reductions in flowers may have unintended consequences for pollinators, particularly in agroecosystems where natural land covers have already been converted. If elimination of weedy forbs is a management goal, enhancing weed removal areas with more desirable, native forbs would help replace the lost forage for bees.

Including non-native forb species in conservation seed mixes is a point of debate within the natural resource community. Although non-native plants play an undeniable role in supporting pollinator communities in human-altered ecosystems, their larger ecological impacts must also be considered before incorporating them in conservation plantings (Bartomeus et al. 2008; Morales and Travest 2009; Valdovinos et al. 2009; Palladini and Maron 2014). This is particularly true for non-native forbs that also exhibit invasive tendencies. Invasive species pose a serious, global threat to native biodiversity (e.g., Chornesky and Randall 2003; Bhowmik 2005, 2014). In our region, Melilotus officinalis, M. alba, and Medicago sativa are likely the most important species for supporting honey production by commercial honey bees. Melilotus spp. may also selectively increase the carrying capacity of local landscapes for native bees (Tepedino et al. 2008) and serve as a central hub of native pollinator networks (Larson et al. 2014; Spellman et al. 2015). However, Melilotus spp. can outcompete native plant communities (Van Riper et al. 2009), thereby degrading habitat quality for other wildlife. Melilotus spp. represent an interesting dilemma for natural resource managers because they are valued by beekeepers for honey production and provide known value to honey bees and other pollinators, yet they can also degrade native grasslands and reconstructed prairie through biological invasion.

\section{Future directions}

Our approach could be applied to estimate the carrying capacity of additional land categories in the PPR for supporting native bees and honey bees. Alternatively, results from our surveys could be applied to determine carrying capacity for particular pollinator species or for honey production. For example, Müller et al. (2006) estimated the number of flowers required to rear single larvae of different bee species. Further, pollen from between 20 and several 1000 flowers is required to rear a single solitary bee larva, and $120 \mathrm{~kg}$ of nectar and $20 \mathrm{~kg}$ of pollen are harvested annually by a single temperate European honey bee colony (Seeley 1995; Müller et al. 2006). Such research could be combined with our estimates of plant species-specific flower abundances to estimate the number of wild bees supported by various grassland categories in the PPR. Beekeepers and policy makers have expressed interest in understanding the number of honey bee colonies that can be supported in the PPR. The estimated number of honey-producing colonies in North Dakota alone rose from 245,000 in 1997 to 455,000 in 2017 (U.S. Department of Agriculture 1999, 2019). This increase in the number of honey bee colonies, combined with the decrease in available forage land in North Dakota, may lead to greater competition within and among honey bees and wild bees and could reduce profitability for beekeepers. Understanding the availability of floral resources for pollinators in this region is an important step in estimating the environmental carrying capacity for honey bees and wild bees. 
Supplementary Information The online version contains supplementary material available at https://doi. org/10.1007/s10531-021-02177-9.

Acknowledgements We thank the numerous field technicians who assisted with plant transect surveys during this study. We thank private landowners for granting us access to their property and USDA staff for assisting us with locating CRP and EQIP enrollments. James Weaver was instrumental in designing the database supporting this effort. We thank Neal Niemuth and two anonymous reviewers for improving the manuscript. All private land information regarding CRP and EQIP were shared through a memorandum of understanding with the USDA. Any use of trade, firm, or product names is for descriptive purposes only and does not imply endorsement by the U.S. Government.

Funding Funding for this research was provided in-part by the United States Department of AgricultureFarm Service Agency (17IAMRECRPHB1), United States Department of Agriculture-Natural Resources Conservation Service (673A7514178), and the Honey Bee Health Coalition and Keystone Policy Center.

Data Availability Flower count data reported in this paper are archived in the U.S. Geological Survey ScienceBase-Catalog (Otto et al. 2020). All land cover data are available at public repositories cited herein. Spatially explicit data associated with the Conservation Reserve program contain proprietary information and are not for public distribution.

Code availability $\mathrm{R}$ code used to conduct analyses have limited availability due to the proprietary nature of the information. Contact the USDA Conservation Reserve Program for more information.

\section{Declarations}

Conflict of interest The authors have no conflicts or competing interests to declare.

\section{References}

Alaux C, Allier F, Decourtye A, Odoux JF, Tamic T, Chabirand M, Delestra E, Decugis F, Le Conte Y, Henry M (2017) A 'Landscape physiology' approach for assessing bee health highlights the benefits of floral landscape enrichment and semi-natural habitats. Sci Rep 7(1):1-10

Bartomeus I, Vila M, Santamaria L (2008) Contrasting effects of invasive plants in plant pollinator networks. Oecologia 155(4):761-770

Bendel CR, Kral-O’Brien KC, Hovick TJ, Limb RF, Harmon JP (2019) Plant-pollinator networks in grassland working landscapes reveal seasonal shifts in network structure and composition. Ecosphere 10(1):e02569

Best LB, Freemark KE, Dinsmore JJ, Camp M (1995) A review and synthesis of habitat use by breeding birds in agricultural landscapes of Iowa. Am Midl Nat 134(1):1-29

Bhowmik PC (2005) Characteristics, significance, and human dimension of global invasive weeds. Invasive plants: ecological and agricultural aspects. Springer, Berlin, pp 251-268

Bhowmik PC (2014) Invasive weeds and climate change: past, present and future. J Crop Weed 10(2):345-349

Black SH, Shepherd M, Vaughan M (2011) Rangeland management for pollinators. Rangelands 33(3):9-13

Bretagnolle V, Gaba S (2015) Weeds for bees? A review Agron Sustain De 35(3):891-909

Brower LP, Fink LS, Walford P (2006) Fueling the fall migration of the monarch butterfly. Integr Comp Biol 46(6):1123-1142

Buri P, Humbert JY, Arlettaz R (2014) Promoting pollinating insects in intensive agricultural matrices: field-scale experimental manipulation of hay-meadow mowing regimes and its effects on bees. PLoS ONE 9(1):e85635

Burke MWV, Rundquist BC, Zheng H (2019) Detection of shelterbelt density change using historic APFO and NAIP aerial imagery. Remote Sensing 11(3):218

Burkle LA, Alarcon R (2011) The future of plant-pollinator diversity: understanding interaction networks across time, space, and global change. Am J Bot 98(3):528-538

Burkle LA, Marlin JC, Knight TM (2013) Plant-pollinator interactions over 120 years: loss of species, co-occurrence, and function. Science 339(6127):1611-1615 
Cameron SA, Lozier JD, Strange JP, Koch JB, Cordes N, Solter LF, Griswold TL (2011) Patterns of widespread decline in North American bumble bees. Proc Nat Acad Sci USA 108(2):662-667

Chornesky EA, Randall JM (2003) The threat of invasive alien species to biological diversity: setting a future course. Ann Missouri Bot Gard 1:67-76

Claassen R, Carriazo F, Cooper J, Hellerstein D, Ueda K (2011) Grassland to cropland conversion in the Northern Plains: The role of crop insurance, commodity, and disaster programs. Economic Research Report No. 120, pp 1-85.

Commission for Environmental Cooperation (2010) North American Rivers and Lakes, hydrography dataset from the North American Atlas. Commission for Environmental Cooperation, Montreal

Darby B, Bryant R, Keller A, Jochim M, Moe J, Schreiner Z, Pratt C, Euliss NH Jr., Park M, Simmons $\mathrm{R}$, Otto C (2020) Molecular sequencing and morphological identification reveal similar patterns in native bee communities across public and private grasslands of eastern North Dakota. PLoS ONE 15(1):e0227918

Decourtye A, Mader E, Desneux N (2010) Landscape enhancement of floral resources for honey bees in agro-ecosystems. Apidologie 41(3):264-277

Evans E, Smart M, Cariveau D, Spivak M (2018) Wild, native bees and managed honey bees benefit from similar agricultural land uses. Agric Ecosys Environ 268:162-170

Fontaine C, Dajoz I, Meriguet J, Loreau M (2005) Functional diversity of plant-pollinator interaction webs enhances the persistence of plant communities. PLoS Biol 4(1):e1

Gallant AL, Euliss NH Jr., Browning Z (2014) Mapping large-area landscape suitability for honey bees to assess the influence of land-use change on sustainability of national pollination services. PLoS ONE 9(6):e99268

Gleason RA, Euliss NH Jr., McDougal RL, Kermes KE, Steadman EN, Harju JA (2005) Potential of restored prairie wetlands in the glaciated North American prairie to sequester atmospheric carbon. USGS North Prairie Wildl Res Center 92:1-17

Gleason RA, Euliss NH Jr., Tangen BA, Laubhan MK, Browne BA (2011) USDA conservation program and practice effects on wetland ecosystem services in the Prairie Pothole Region. Ecol Appl 21(sp1):S65-S81

Haas CA (1995) Dispersal and use of corridors by birds in wooded patches on an agricultural landscapes. Conserv Biol 9(4):845-854

Hopwood J, Hoffman Black S, Lee-Mader E, Charlap A, Preston R, Mozumder K, Fleury S (2015) Literature review: pollinator habitat enhancement and best management practices in highway rightsof-way. The Xerces Society for invertebrate conservation and ICF International. Federal Highway Administration, Washington, DC

Hudewenz A, Klein AM, Scherber C, Stanke L, Tscharntke T, Vogel A, Weigelt A, Weisser WW, Ebeling A (2012) Herbivore and pollinator responses to grassland management intensity along experimental changes in plant species richness. Biol Conserv 150(1):42-52

Johnson KA, Dalzell BJ, Donahue M, Gourevitch J, Johnson DL, Karlovits GS, Keeler B, Smith JT (2016) Conservation Reserve Program (CRP) lands provide ecosystem service benefits that exceed land rental payment costs. Ecosys Serv 18:175-185

Koh I, Lonsdorf EV, Williams NM, Brittain C, Isaacs R, Gibbs J, Ricketts TH (2016) Modeling the status, trends, and impacts of wild bee abundance in the United States. Proc Nat Acad Sci USA 113(1):140-145

Kremen C, Williams NM, Aizen MA, Gemmill-Herren B, LeBuhn G, Minckley R, Packer L, Potts SG, Roulston T, Steffan-Dewenter I, Vazquez DP, Winfree R, Adams L, Crone EE, Greenleaf SS, Keitt TH, Klein AM, Regetz J, Ricketts TH (2007) Pollination and other ecosystem services produced by mobile organisms: a conceptual framework for the effects of land-use change. Ecol Lett 10(4):299-314

Kwaiser KS, Hendrix SD (2008) Diversity and abundance of bees (Hymenoptera: Apiformes) in native and ruderal grasslands of agriculturally dominated landscapes. Agric Ecosys Environ 124:200-204

Lane IG, Herron-Sweet CR, Portman ZM, Cariveau DP (2020) Floral resource diversity drives bee community diversity in prairie restorations along an agricultural landscape gradient. J Appl Ecol 57(10):2010-2018

Lark TJ, Salmon JM, Gibbs HK (2015) Cropland expansion outpaces agricultural and biofuel policies in the United States. Environ Res Lett 10(4):044003

Larson DL, Droege S, Rabie PA, Larson JL, Devalez J, Haar M, McDermott-Kubeczko M (2014) Using a network modularity analysis to inform management of a rare endemic plant in the northern Great Plains, USA. J Appl Ecol 51:1024-1032

M'Gonigle LK, Williams NM, Lonsdorf E, Kremen C (2017) A tool for selecting plants when restoring habitat for pollinators. Conserv Lett 10(1):105-111 
Mann GE (1974) The Prairie Pothole Region — a zone of environmental opportunity. Naturalist 25(4):2-7

Mattila HR, Otis GW (2007) Dwindling pollen resources trigger the transition to broodless populations of long-lived honeybees each autumn. Ecol Entomol 32(5):496-505

Minnesota Department of Natural Resources (2018) Publicly Accessible State Wildlife Management Areas. Minnesota Department of Natural Resources, St Paul

Minnesota Department of Transportation (2001) Chapter 8: drainage design and erosion control. Road design manual. Minnesota Department of Transportation, St Paul

Minnesota Department of Transportation (2012) Chapter 4: cross sections. Road design manual. Minnesota Department of Transportation, St Paul

Morales CL, Travest A (2009) A meta-analysis of impacts of alien vs. native plants on pollinator visitation and reproductive success of co-flowering native plants. Ecol Lett 12(7):716-728

Müller A, Diener S, Schnyder S, Stutz K, Sedivy C, Dorn S (2006) Quantitative pollen requirements of solitary bees: implications for bee conservation and the evolution of bee-flower relationships. Biol Conserv 130:604-615

Naugle DE, Johnson RR, Estey ME, Higgins KF (2001) A landscape approach to conserving wetland bird habitat in the Prairie Pothole Region of eastern South Dakota. Wetlands 21(1):1-17

Niemuth ND, Estey ME, Loesch CR (2005) Developing spatially explicit habitat models for grassland bird conservation planning in the Prairie Pothole Region of North Dakota. USDA Forest Service Gen Tech Rep PSW-GTR-191, Albany, pp 461-477

North Dakota Department of Transportation (2017) Design guidelines. Design Manual. North Dakota Department of Transportation, Bismarck

North Dakota Game and Fish Department (2018) Wildlife Management Areas. North Dakota Game and Fish Department, Bismarck

Oberhauser K, Wiederholt R, Diffendorfer JE, Semmens D, Ries L, Thogmartin WE, Lopez Hoffman L, Semmens B (2017) A trans-national monarch butterfly population model and implications for regional conservation priorities. Ecol Entomol 42(1):51-60

Oksanen J, Guillaume Blanchet F, Friendly M, Kindt R, Legendre P, McGlinn D, Minchin PR, O’Hara RB, Simpson GL, Solymos P, Henry M, Stevens H, Szoecs E, Wagner H (2020) Vegan: community ecology package. R package version 2.5-7. Available at https://CRAN.R-project.org/package=vegan

Ollerton J, Winfree R, Tarrant S (2011) How many flowering plants are pollinated by animals? Oikos 120(3):321-326

Orford KA, Murray PJ, Vaughan IP, Memmott J (2016) Modest enhancements to conventional grassland diversity improve the provision of pollination services. J Appl Ecol 53(3):906-915

Otto CRV, Roth CL, Carlson BL, Smart MD (2016) Land-use change reduces habitat suitability for supporting managed honey bee colonies in the Northern Great Plains. Proc Nat Acad Sci USA 113(37):10430-10435

Otto CRV, O’Dell S, Bryant RB, Euliss NH, Bush RM, Smart MD (2017) Using publicly available data to quantify plant-pollinator interactions and evaluate conservation seeding mixes in the Northern Great Plains. Environ Entomol 46(3):565-578

Otto CRV, Zheng H, Gallant AL, Iovanna R, Carlson BL, Smart MD, Hyberg S (2018) Past role and future outlook of the Conservation Reserve Program for supporting honey bees in the Great Plains. Proc Nat Acad Sci USA 115(29):7629-7634

Otto C, Simanonok S, Smart A, Simanonok M (2020) Dataset: plant and bee transects in the Northern Great Plains, USA 2015-2019. U.S. Geological Survey, Reston. https://doi.org/10.5066/P9O61BCB

Palladini JD, Maron JL (2014) Reproduction and survival of a solitary bee along native and exotic floral resource gradients. Oecologia 176(3):789-798

Pengyao L, Kleijn D, Badenhausser I, Zaragoza-Trello C, Gross N, Raemakers I, Scheper J (2020) The relative importance of green infrastructure as refuge habitat for pollinators increases with local land-use intensity. J Appl Ecol 57(8):1494-1503

Phillips BB, Wallace C, Roberts BR, Whitehouse AT, Gaston KJ, Bullock JM, Dicks LV, Osborne JL (2020) Enhancing road verges to aid pollinator conservation: a review. Biol Conserv 250:108687

Pimentel D (2003) Ethanol fuels: energy balance, economics, and environmental impacts are negative. Nat Resour Res 12(2):127-134

Pollinator Health Task Force (2015) National strategy to promote the health of honey bees and other pollinators. The White House, Washington, DC

Potts SG, Biesmeijer JC, Kremen C, Neumann P, Schweiger O, Kunin WE (2010) Global pollinator declines: trends, impacts and drivers. Trends Ecol Evol 25(6):345-353

R Core Team (2020) R: a language and environment for statistical computing. R Foundation for Statistical Computing, Vienna 
Rashford BS, Walker JA, Bastian CT (2011) Economics of grassland conversion to cropland in the Prairie Pothole Region. Conserv Biol 25(2):276-284

Ribbands CR (1951) The flight range of the honey-bee. J Animal Ecol 20:220-226

Ricigliano VA, Mott BM, Maes PW, Floyd AS, Fitz W, Copeland DC, Meikle WG, Anderson KE (2019) Honey bee colony performance and health are enhanced by apiary proximity to US Conservation Reserve Program (CRP) lands. Sci Rep 9(1):1-11

Rotheray EL, Osborne JL, Goulson D (2017) Quantifying the food requirements and effects of food stress on bumble bee colony development. J Apicul Res 56(3):288-299

Samson F, Knopf F (1994) Prairie conservation in North America. Bioscience 44(6):418-421

Scasta JD, Thacker ET, Hovick TJ, Engle DM, Allred BW, Fuhlendorf SD, Weir JR (2016) Patch-burn grazing $(\mathrm{PBG})$ as a livestock management alternative for fire-prone ecosystems of North America. Renew Agricul Food Syst 31(6):550-567

Schaefer PR, Dronen S, Erickson D (1987) Windbreaks: a plains legacy in decline. J Soil Water Conserv 42(4):237-238

Schlaepfer MA, Sax DF, Olden JD (2011) The potential conservation value of non-native species. Conserv Biol 25(3):428-437

Searchinger T, Heimlich R, Houghton RA, Dong F, Elobeid A, Fabiosa J, Tokgoz S, Hayes D, Yu TH (2008) Use of U.S. cropland for biofuels increases greenhouse gases through emissions from landuse change. Science 319(5867):1238-1240

Seeley TD (1995) The wisdom of the hive: the social physiology of honey bee colonies. Harvard University Press, Cambridge

Seelig B, DeKeyser S (2006) Water quality and wetland function in the Northern Prairie Pothole Region. NDSU Extension Service.2222223WQ-1313. pp 1-29

Senapathi D, Goddard MA, Kunin WE, Baldock KC (2017) Landscape impacts on pollinator communities in temperate systems: evidence and knowledge gaps. Funct Ecol 31(1):26-37

Sexton AN, Emery SM (2020) Grassland restorations improve pollinator communities: a meta analysis. J Insect Conserv 24:719-726

Simanonok S, Otto CRV (2020) Flowering plants preferred by bees of the Prairie Pothole Region: U.S. Geological Survey Fact Sheet 2020-3038. U.S. Geological Survey, Reston

Sjodin NE (2007) Pollinator behavioural responses to grazing intensity. Biodivers Conserv 16(7):2103-2121

Smart M, Pettis J, Rice N, Browning Z, Spivak M (2016) Linking measures of colony and individual honey bee health to survival among apiaries exposed to varying agricultural land use. PLoS ONE 11(3):e0152685

Smart MD, Cornman RS, Iwanowicz DD, McDermott-Kubeczko M, Pettis JS, Spivak MS, Otto CRV (2017) A comparison of honey bee-collected pollen from working agricultural land using light microscopy and ITS metabarcoding. Environ Entomol 46(1):38-49

Smart MD, Otto CRV, Carlson BL, Roth CL (2018) The influence of spatiotemporally decoupled land use on honey bee colony health and pollination service delivery. Environ Res Lett 13:084016

South Dakota Department of Transportation (2018) Chapter 7: cross sections. Road design manual. South Dakota Department of Transportation, Pierre

Spellman KV, Schneller LC, Mulder CPH, Carlson ML (2015) Effects of non-native Melilotus albus on pollination and reproduction in two boreal shrubs. Oecologia 179:495-507

Tepedino VJ, Bradley BA, Griswold TL (2008) Might flowers of invasive plants increase native bee carrying capacity? Intimations from Capitol Reef National Park, Utah. Nat Areas J 28(1):44-50

Thogmartin WE, Lopez-Hoffman L, Rohweder J, Diffendorfer J, Drum R, Semmens D, Black S, Caldwell I, Cotter D, Drobney P, Jackson LL, Gale M, Helmers D, Hilburger S, Howard E, Oberhauser K, Pleasants J, Semmens B, Taylor O, Ward P, Weltzin JF, Wiederholt R (2017) Restoring monarch butterfly habitat in the Midwestern US: 'all hands on deck.' Environ Res Lett 12(7):074005

Tillman D, Socolow R, Foley JA, Hill J, Larson E, Lynd L, Pacala S, Reilly J, Searchinger T, Somerville C, Williams R (2009) Beneficial biofuels - The food, energy, and environment trilemma. Science 325(5938):270-271

U.S. Department of Agriculture, National Agricultural Statistics Service (1999) Honey. U.S. Department of Agriculture, National Agricultural Statistics Service, Washington, D.C.

U.S. Department of Agriculture, National Agricultural Statistics Service (2018) Cropland Data Layer for 2017. U.S. Department of Agriculture, National Agricultural Statistics Service, Washington, D.C.

U.S. Department of Agriculture, National Agricultural Statistics Service (2019) Honey. U.S. Department of Agriculture, National Agricultural Statistics Service, Washington, D.C.

U.S. Department of Agriculture, Natural Resources Conservation Service (2020) The PLANTS Database. National Plant Data Team, Greensboro 
U.S. Geological Survey (2018) National transportation dataset downloadable data collection. U.S. Geological Survey, Reston

U.S. Geological Survey, Gap Analysis Program (2016) Protected Areas Database of the United States (PADUS), version 14 Combined Feature Class. U.S. Geological Survey, Reston

Valdovinos FS, Ramos-Jiliberto R, Flores JD, Espinoza C, Lopez G (2009) Structure and dynamics of pollination networks: the role of alien plants. Oikos 118(8):1190-1200

Van Riper LC, Larson DL (2009) Role of invasive Melilotus officinalis in two native plant communities. Plant Ecol 200:129-139

Vickruck JL, Best LR, Gavin MP, Devries JH, Galpern P (2019) Pothole wetlands provide reservoir habitat for native bees in prairie croplands. Biol Conserv 232:43-50

Westphal C, Steffan-Dewenter I, Tscharntke T (2003) Mass flowering crops enhance pollinator densities at a landscape scale. Ecol Lett 6:961-965

Whigham DF, Jordan TE (2003) Isolated wetlands and water quality. Wetlands 23(3):541-549

Williams NM, Ward KL, Pope N, Isaacs R, Wilson J, May EA, Ellis J, Daniels J, Pence A, Ullmann K, Peters J (2015) Native wildflower plantings support wild bee abundance and diversity in agricultural landscapes across the United States. Ecol Appl 25(8):2119-2131

Winfree R, Aguilar R, Vazquez DP, LeBuhn G, Aizen MA (2009) A meta-analysis of bees' responses to anthropogenic disturbance. Ecology 90(8):2068-2076

Winfree R, Bartomeus I, Cariveau DP (2011) Native pollinators in anthropogenic habitats. Annu Rev Ecol Evol Sys 42:1-22

Wright CK, Wimberly MC (2013) Recent land use change in the Western Corn Belt threatens grasslands and wetlands. Proc Nat Acad Sci USA 110(10):4134-4139

Yahner RH (1983) Small mammals in farmstead shelterbelts: Habitat correlates of seasonal abundance and community structure. J Wildl Manag 47(1):74-84

Publisher's Note Springer Nature remains neutral with regard to jurisdictional claims in published maps and institutional affiliations.

\section{Authors and Affiliations}

\section{Autumn H. Smart ${ }^{1,2}$ - Clint R. V. Otto ${ }^{2}$ - Alisa L. Gallant ${ }^{3}$. Michael P. Simanonok ${ }^{2}$ (D)}

1 Department of Entomology, University of Nebraska-Lincoln, Lincoln, NE 68583, USA

2 U.S. Geological Survey, Northern Prairie Wildlife Research Center, Jamestown, ND 58401, USA

3 U.S. Geological Survey, Earth Resources Observation and Science Center, Sioux Falls, SD 57198, USA 


\section{Supplementary Files}

\section{Supplementary file1}

Table 1. USDA Conservation Reserve Program (CRP) and Environmental Quality Incentives Program (EQIP) practices on which we conducted plant surveys. (CSV $1 \mathrm{~KB}$ )

\section{Supplementary file2}

Table 2. Number of surveys conducted among grassland classes and grassland categories by season (early, mid-, late) and year (2015 - 2018) in the Prairie Pothole Region of the United States. BBHF $=$ Bee and Butterfly Habitat Fund; CRP $=$ Conservation Reserve Program; CP-42 $=\mathrm{CRP}$ Conservation Practice 42 (Pollinator Habitat); EQIP $=$ Environmental Quality Incentives Program; WMA = Wildlife Management Area; WPA = Waterfowl Production Area. (CSV 4 $\mathrm{KB})$

\section{Supplementary file3}

Table 3. Flower abundances (floral stem counts) of all blooming plants (scientific and common names) observed flowering on transects from 2015 - 2018, and the grassland classes, categories, and practices on which they were surveyed in the Prairie Pothole Region of the United States. Indigenous status (native or introduced) is according to the USDA PLANTS database (https://plants.sc.egov.usda.gov/java/). BBHF = Bee and Butterfly Habitat Fund; CRP = Conservation Reserve Program; CP-42 = CRP Conservation Practice 42 (Pollinator Habitat); $\mathrm{EQIP}=$ Environmental Quality Incentives Program; WMA = Wildlife Management Area; WPA $=$ Waterfowl Production Area. $(\mathrm{CSV} 139 \mathrm{~KB})$

\section{Supplementary file4}

Fig 1. Mean floral stem abundance per transect of native and introduced plants among surveyed major grassland classes by season, 2015-2018 in the Prairie Pothole Region of the United States. Errors bars represent the standard error of the mean (SEM). (TIFF $7911 \mathrm{~KB}$ )

\section{Supplementary file5}

Fig 2. Mean flower stem abundance per transect among surveyed grassland categories by season, 2015-2018 in the Prairie Pothole Region of the United States. Errors bars represent the standard 
error of the mean $(\mathrm{SEM}) . \mathrm{BBHF}=$ Bee and Butterfly Habitat Fund; CRP $=$ Conservation Reserve Program; CP-42 = CRP Conservation Practice 42 (Pollinator Habitat);EQIP = Environmental Quality Incentives Program; WMA = Wildlife Management Area; WPA = Waterfowl Production Area. (TIFF 7911 KB)

\section{Supplementary file6}

Fig 3. Mean plant species richness per transect of native and introduced plants among surveyed major grassland classes, 2015-2018 in the Prairie Pothole Region of the United States. Errors bars represent the standard error of the mean (SEM). (TIFF $7911 \mathrm{~KB}$ )

\section{Supplementary file7}

Fig 4. Mean plant species richness per transect among surveyed grassland categories, 2015-2018 in the Prairie Pothole Region of the United States. Errors bars represent the standard error of the mean $(\mathrm{SEM})$. BBHF $=$ Bee and Butterfly Habitat Fund; CP-42 = CRP Conservation Practice 42 (Pollinator Habitat); CRP = Conservation Reserve Program; EQIP = Environmental Quality Incentives Program; WMA = Wildlife Management Area; WPA = Waterfowl Production Area. (TIFF $7911 \mathrm{~KB}$ )

\section{Supplementary file8}

Fig 5. Principle coordinates analysis (PCO) plot comparing Grassland Class and Season of sampling in the Prairie Pothole Region of the United States. Each point represents a single transect survey. Black circles are Conservation Grassland; orange triangles are Engineered Pollinator Habitat; and blue squares are General Grassland. Panel A is Early-season (June 16July 15); B is Mid-season (July 16-August 15); and C is Late-season (August 16-September 15). (TIFF $3692 \mathrm{~KB}$ )

\section{Supplementary file9}

Fig 6. Mean floral stem abundance and plant species richness per transect among conservation programs and practices on private lands in the Prairie Pothole Region of the United States.Letters denote significant differences $(\alpha \leq 0.05)$ and errors bars represent the standard error of the mean (SEM). All conservation practices with less than 50 transect sampling events were removed prior to analysis. $\mathrm{CP}=$ Conservation Reserve Program Conservation Practice; EQIP = Environment Quality Incentives Program. (TIFF 9229 KB) 
